\title{
Berkebun Sayur dengan Teknik Vertikultur sebagai Upaya Peningkatan Ketahanan Pangan Santri Panti Asuhan Jatibening Bekasi
}

\author{
Verticulture Farming as An Effort for Food Security of Orphanage in Jatibening Bekasi
}

\begin{abstract}
Sri Rahayu ${ }^{1^{*}}$
Dian Ekawati ${ }^{2}$

${ }^{1}$ Department of Biology, Universitas Negeri Jakarta, East Jakarta, Jakarta Capital Special Region, Indonesia

2Department of Biology Education, Universitas Negeri Jakarta, East Jakarta, Jakarta Capital Special Region, Indonesia
\end{abstract}

*email: srirahayu@unj.ac.id

\section{Kata Kunci \\ Berkebun \\ Pangan \\ Vertikultur \\ Keywords: \\ Gardening \\ Food \\ Verticulture}

Received: April 2020

Accepted: November 2020

Published: December 2020

\begin{abstract}
Abstrak
Tingkat konsumsi sayuran di Indonesia sangatlah rendah dibanding standar yang telah ditetapkan. Berbagai faktor menjadi penyebab rendahnya angka konsumsi sayur antara lain faktor ekonomi dan pengetahuan. Santri di panti asuhan yatim di Jatibening sebagian besar kurang mengkonsumsi sayuran dikarenakan kurangnya pengetahuan dan alasan ekonomi. Seluruh santri di panti asuhan ini berasal dari golongan tidak mampu sedangkan sejak tahun 2012 panti asuhan sudah tidak mendapatkan subsidi dana dari pemerintah dalam operasionalnya. Kegiatan ini bertujuan memberikan pengetahuan dan ketrampilan bagi santri di panti asuhan Al Hidayah serta menyediakan vertikultur tanaman sayur untuk meningkatkan ketahanan pangan santri. Pendekatan metode yang dilakukan adalah metode partisipasi aktif masyarakat (PAM) dimana masyarakat dilibatkan secara langsung dalam kegiatan. Tahapan metode pretest, pemberian materi, posttest, demonstrasi pembuatan vertikultur tanaman sayur dan redemonstrasi oleh santri. Tanaman yang dibudidayakan adalah sawi, bayam dan toge. Kegiatan dilaksanakan di panti asuhan Al Hidayah Jati Bening pada hari Minggu 1 Oktober 2017. Kegiatan ini diikuti oleh 20 orang peserta dari panti asuhan Al Hidayah Dan Roisul Falah Jatibening Bekasi. Berdasarkan hasil pretest dan posttest diperoleh peningkatan pengetahuan sebesar 72,43\%. Dapat disimpulkan bahwa terdapat peningkatan pengetahuan mengenai vertikultur dan ketrampilan dalam membuat vertikultur tanaman sayur seperti yang di demosntrasikan. Kegiatan ini menghasilkan vertikultur di panti asuhan al hidayah yang dapat dimanfaatkan santri di panti asuhan untuk memenuhi kebutuhan akan sayuran.
\end{abstract}

\begin{abstract}
The level of vegetable consumption in Indonesia is shallow compared to the standards that have been set. Various factors contributed to the low rate of vegetable consumption, including economic factors and knowledge. Most of the santri at the orphanage in Jatibening consume fewer vegetables due to lack of knowledge and economic reasons. All students in this orphanage come from underprivileged groups, whereas since 2012, the orphanage has not received subsidies from the government for its operations. This activity aims to provide knowledge and skills for students at the Al Hidayah orphanage and provide vegetable plant verticulture to improve the students' food security. The method approach used is the active community participation (PAM) method in which the community is directly involved in activities. The pretest method stages, providing material, post-test, demonstration of making vegetable plant verticulture and redemonstration by students. The plants cultivated are mustard greens, spinach, and bean sprouts. The activity was held at the Al Hidayah Jati Bening orphanage on Sunday, 1 October 2017. This activity was attended by 20 participants from the Al Hidayah and Roisul Falah Jatibening orphanage Bekasi. Based on the pre-test and post-test results, it was obtained an increase in knowledge of $72.43 \%$. It can be concluded that there is an increase in knowledge about verticulture and skills in making vegetable plant verticulture as demonstrated. This activity resulted in verticulture at the Al Hidayah orphanage that could be used by students at the orphanage to meet the need for vegetables.
\end{abstract}




\section{PENDAHULUAN}

Tingkat konsumsi sayuran di Indonesia sangatlah rendah. Banyak hambatan yang dihadapi dalam meningkatkan konsumsi sayur di Indonesia. Banyaknya sumber sayuran yang sudah dicemari pestisida membuat sebagian besar masyarakat enggan mengkonsumsi sayuran (Rinawati \& Sofiatun, 2019). Selain itu faktor ekonomi menjadi penyebab lain minimnya konsumsi dimasyarakat. Pengetahuan mengenai pentingnya mengkonsumsi sayuran juga turut menjadi penyebab minimnya konsumsi sayuran di masyarakat (Raharto et al., 2008).

Peraturan presiden nomor 22 tahun 2009 tentang kebijakan Percepatan Penganekaragaman Konsumsi Pangan berbasis Sumber Daya Lokal tanggal 6 Juni 2009 menjadikan peraturan ini digunakan sebagai dasar dalam pelibatan masyarakat secara aktif dalam budidaya pangan. Perpres ini ditujukan untuk mendorong percepatan penganekaragaman konsumsi pangan berbasis sumberdaya lokal melalui kerjasama sinergis antara pemerintah, pemerintah daerah dan masyarakat serta universitas. Berbagai inovasi diperlukan untuk merealisasi perpres tersebut, salah satunya adalah dengan pemanfaatan lahan terbatas di sekitar rumah dan lingkungan untuk menghasilkan bahan pangan yang sehat dan bermanfaat (Dhunita, 2015).

Salah satu bahan pangan yang dapat diupayakan adalah budidaya tanaman sayur karena tidak memerlukan lahan yang luas dan bisa dilakukan di areal sekitar rumah (Ashariet al., 2012). Budidaya sayuran memegang peranan penting dan strategis untuk meningkatkan keanekaragaman pola konsumsi pangan dan peningkatan gizi masyarakat (Rachman \& Ariani, 2008). Pekarangan bisa menjadi sumber kebutuhan sayuran sehingga tingkat konsumsi sayuran di Indonesia dapat meningkat (Sarno, 2019). Selain itu budidaya sayuran di pekarangan memungkinkan sayuran yang dihasilkan dan akan dikonsumsi bebas dari pestisida dan bahan kimia berbahaya (Amilia et al., 2016).

Panti asuhan yatim Al Hidayah dan Roisul Falah merupakan panti asuhan yang berlokasi di kelurahan Jatibening Kecamatan Pondok Gede Jawa Barat. Panti asuhan ini terletak di tengah-tengah masyarakat di kelurahan jati bening bekasi. Sebagian besar masyarakat di sekitar kelurahan jati bening, bekasi merupakan masyarakat pendatang dengan tingkat ekonomi bawah. Awal pendirian panti asuhan pada tahun 1979 dimulai dengan adanya rasa kemanusiaan beberapa pemuka agama di wilayah jati bening terhadap anak- anak yang saat itu ditinggal mati orangtuanya terutama ayah mereka. Kaum Pria di wilayah ini sebagian besar bekerja sebagai buruh sedangkan kaum wanita umumnya hanya ibu rumah tangga yang tidak memiliki penghasilan sama sekali. Pada saat suami dan ayah mereka meninggal, ibu tidak dapat lagi memenuhi kebutuhan keluarga terutama sekolah anak- anak mereka. Hal inilah yang mendasari motivasi pemuka agama di wilayah ini untuk mendirikan panti asuhan yang terutama ditujukan untuk tetap menyekolahkan anak- anak yatim ini. Pada awalnya, santri di panti asuhan hanyalah berasal dari wilayah Jati Bening dan sekitarnya namun seiring perkembangan waktu dan meluasnya informasi, panti asuhan ini menerima santri dari seluruh wilayah di Indonesia. Panti Asuhan ini memberikan tempat perlindungan, makanan, pakaian dan terutama pendidikan bagi anak yatim hingga jenjang Sekolah menengah Atas. Panti asuhan ini berada di lingkungan RT 03 dan RW 03 Panti asuhan memiliki luas wilayah $250 \mathrm{~m}^{2}$. Jumlah santri pada panti asuhan ini adalah sebanyak 40 orang yang terdiri dari 25 perempuan dan 15 laki- laki. Dari seluruh santri, semuanya bersekolah di sekitar kawasan Jatibening dari jenjang SD hingga SMA. 
Semua santri di panti asuhan beragama islam dan terlibat aktif dalam kegiatan- kegiatan keagamaan di mushola Al Hidayah dan mushola Roisul Falah yang juga dikelola oleh ketua pondok pesantren. Mereka juga aktif membantu warga sekitar yang membutuhkan bantuan dalam berbagai hal, seperti membersihkan sampah hingga membantu pengangkutan sampah ke truk sampah setiap minggu, Membantu warga membersihkan selokan dan rumput-rumput liar, membantu memberikan pengajaran iqro bagi anak-anak kecil di lingkungan panti asuhan.

Semua santri di panti asuhan merupakan santri yang dititipkan oleh keluarga mereka sejak mereka yatim dikarenakan ketidakmampuan keluarga untuk membiayai mereka. Hal ini menyebabkan panti asuhan merupakan tempat penitipan Cuma- Cuma bagi anakanak yatim (Fuaida, 2012). Sejak beberapa tahun belakangan jumlah santri meningkat. Semakin banyaknya santri yang dititipkan di pondok pesantren ini menyebabkan dana donatur yang diperoleh kurang dapat memenuhi kebutuhan santri dengan layak. Ditambah lagi sudah tidak ada lagi dana bantuan dari pemda setempat bagi panti sejak tahun 2012. Hal ini dapat terlihat dari fasilitas panti asuhan yang sudah mulai tidak layak untuk untuk jumlah santri yang ada dengan tempat tidur dan kamar mandi. Selain itu, bahan pangan yang disajikan untuk santri semakin minim dan sangat jauh dari standar gizi yang baik. Pengetahuan serta pemahaman mengenai pentingnya konsumsi makanan bergizi kurang dapat didukung dengan kemampuan finansial seluruh santri di panti asuhan ini. Bahan pangan yang mereka olah biasanya dibeli dari pedagang sayur sekitar panti. Santri tidak memahami bahwa sebenarnya mereka bisa memproduksi sendiri bahan pangan yang bisa dikonsumsi terutama sayur mayur yang cukup dengan memanfaatkan lahan yang mereka miliki. Namun semua santri mengaku tidak terlalu faham mengenai berkebun sayuran dengan lahan yang sempit di pekarangan panti asuhan mereka. Mereka juga berpendapat tidak memiliki ketrampilan memadai dalam memproduksi sendiri sayuran di panti asuhan mereka.

Pekarangan panti merupakan lahan terbuka yang dapat dimanfaatkan santri untuk menghasilkan sayuran yang dapat dimanfaatkan oleh santri panti asuhan sendiri (Zubaidah et al., 2020). Dengan sistem pertanian vertikultur menggunakan pipa paralon, lahan sesempit apapun dapat digunakan untuk menghasilkan berbagai sayuran yang cukup memadai. Teknik ini juga dapat di terapkan si pekarangan panti yang juga kurang luas. Dengan luas area yang sama, teknik ini mampu menghasilkan sayur lebih banyak dari teknik konvensional (Yasin \& Kasim, 2018). Dengan cara tersebut, panti asuhan tidak perlu lagi membeli sayuran dan dapat mengambil sendiri sayuran dari pekarangan mereka yang lebih dekat, aman dan tanpa biaya. Berdasarkan analisis tersebut maka perlu dilakukan pelatihan berkebun sayur di lahan sempit dengan menggunakan pipa paralon.

Kegiatan ini bertujuan memberikan pengetahuan dan ketrampilan bagi santri di panti asuhan Al Hidayah serta menyediakan vertikultur tanaman sayur untuk meningkatkan ketahanan pangan santri. Target luaran yang dihasilkan dari kegiatan ini adalah peningkatan pemahaman santri mengenai pentingnya konsumsi sayur dan budidaya sayur di lahan sempit. Selain itu diharapkan terdapat pula peningkatan keterampilan santri dalam membuat kebun sayur organik dengan menggunakan pipa paralon. Luaran lain yang diharapkan adalah tersedianya kebun sayur dengan menggunakan pipa paralon di lingkungan panti asuhan yang daat dimanfaatkan bagi kebutuhan santri di panti asuhan. 


\section{METODOLOGI}

Alat yang digunakan dalam kegiatan ini antara terdiri atas alat semai bibit dan medium serta pot vertikultur dari bambu. Kegiatan ini menerapkan sistem PAM (Partisipasi Aktif Masyarakat) dimana masyarakat dilibatkan secara penuh pada kegiatan yang dilaksanakan. Kegiatan dibagi dalam beberapa tahap.

\section{Tahap Persiapan}

Pada tahap ini dilakukan persiapan berupa persiapan materi pelatihan. Materi yang digunakan adalah materi mengenai pentingnya mengkonsumsi sayuran bagi kesehatan dan materi pelatihan cara berkebun sayuran dengan menggunakan pipa paralon. Selain itu dilakukan pula persiapan berupa alat dan bahan yang digunakan dalam kegiatan termasuk bibit sayur yang akan dibudidaya. Dalam kegiatan ini dipilih 3 jenis sayur yang akan di budidaya yaitu sawi, bayam dan tauge. Persiapan lain dilakukan dengan membuat soal pre test dan post test untuk mengevaluasi peningkatan pengetahuan dan pemahaman santri. Dilakukan pula perijinan kepada kepala panti asuhan serta penetapan waktu pelaksanaan kegiatan.

\section{Tahap Pelaksanaan}

Pada tahap pelaksanaan terlebih dahulu dilakukan pre test pada para santri mengenai pengetahuan pentingnya konsumsi sayuran bagi kesehatan dan teknik budidaya sayuran di lahan sempit. Kegiatan inti dilaksanakan dalam dua sesi. Sesi pertama dilakukan pemberian materi mengenai pentingnya mengkonsumsi sayur dan teknik budaya sayuran di lahan smepit dengan paralon. Sesi kedua dilanjutkan dengan demonstrasi dan redemosntrasi cara berkebun dengan menggunakan pipa.

\section{Tahap Evaluasi}

Tahap evaluasi dilakukan dalam beberapa bagian. Bagian pertama adalah evaluasi kegiatan dengan memberikan pre test dengan soal post test yang sama. Bagian kedua evaluasi dilakukan dengan monitoring keberlangsungan budidaya sayur pada 1 bulan setelah kegiatan

\section{HASIL DAN PEMBAHASAN}

Kegiatan pengabdian masyarakat di panti asuhan Bening. Kegiatan dilaksanakan di aula panti asuhan $\mathrm{Al}$ hidayah yang diikuti oleh 20 orang peserta. Peserta kegiatan adalah santri panti asuhan al hidayah dan panti asuhan roisul falah. Seluruh peserta adalah santri lakilaki yang berusia $12-17$ tahun.

Tahapan awal yang dilakukan adalah pemberian soal pretest berjumlah 10 soal unttuk mengetahui pemahaman santri tentang vertikultur dan berkebun sayur. Selanjutnya diberikan materi mengenai apa itu vertikultur dan bertanam sayur dengan vertikultur. Kegiatan dilanjutkan dengan pemberian soal posttest berjumlah 10 soal untuk menilai pengetahuan santri setelah diberikan materi. Hasil pretest dan post test terlihat pada Gambar 1 dan 2.

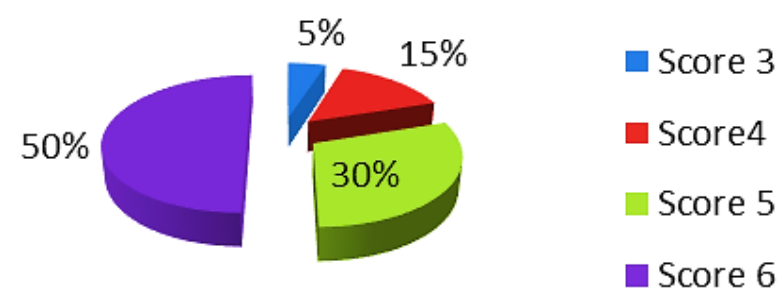

Gambar 1. Nilai pretest santri tentang vertikultur tanaman sayur

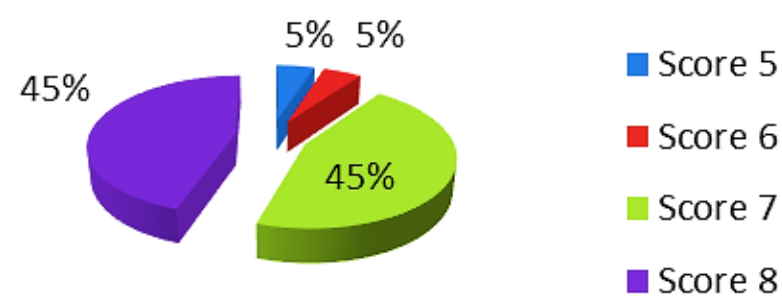

Gambar 2. Nilai posttest santri tentang vertikultur tanaman sayur

Berdasarkan hasil pretest dan posttest diketahui terdapat peningkatan rata-rata nilai santri setelah diberikan materi 
mengenai vertikultur dan berkebun sayur seperti ditunjukkan pada Gambar 3. Rata- rata peningakatan nilai yang diperoleh sebesar $72.41 \%$.

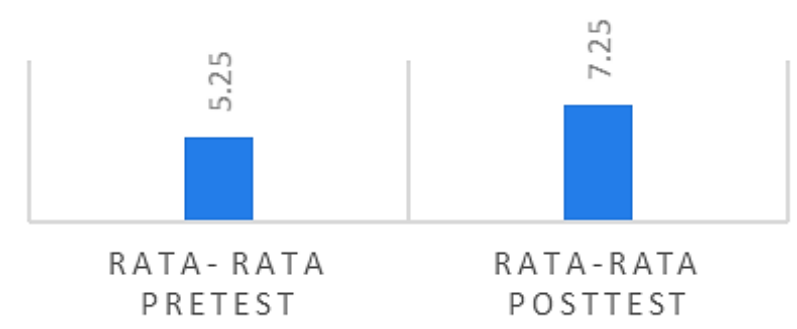

Gambar 3. Rata-rata nilai pretest dan posttest peserta

Berdasarkan hasil pretest dan posttest seluruh peserta kegiatan (santri) mengalami peningkatan nilai posttest dibandingkan saat pretest seperti ditunjukkan pada Gambar 4. Hal ini sesuai dengan pendapat lain bahwa penyuluhan dapat meningkatkan pengetahuan maasyarakat (Wachidjono et al., 2019).

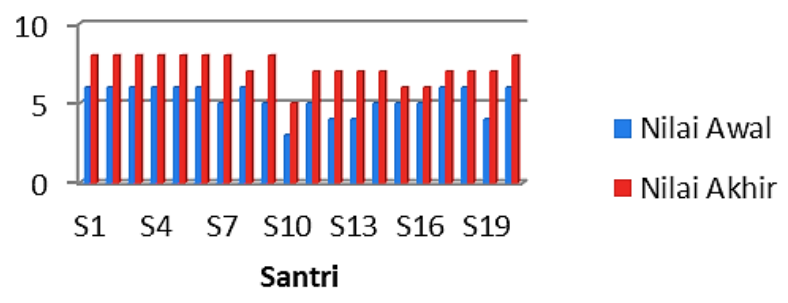

Gambar 4. Nilai tes awal dan akhir santri peserta PKM

Tahapan selanjutnya dilakukan demonstrasi pembuatan vertikultur dengan bahan paralon dan bertanam sayur. Demonstrasi cara bertanam sayur dengan mengunakan teknik vertikultur. Pertama kali peserta diajarkan mengenai bagaimana cara memilih bibit tanaman yang baik untuk ditanam. Pemilihan bibit yang baik dilakukan dengan merendam bibit tanaman di air selama 5 menit (Prihmantoro, 2006). Ciri-ciri bibit tanaman yang baik adalah bibit yang dapat tenggelam pada saat direndam (Syahcruddin et al., 2019; Abubakar et al., 2019). Bibit sayuran yang dipilih adalah bibit bayam, kangkung, sawi dan tauge. Bibit-bibit tersebut dipilih karena beberapa alasan. Alasan pemilihan bibit tersebut adalah kemudahan dalam perawatan, cepatnya masa panen dan ketahanan terhadap penyakit. Bibit sawi, kangkung dan bayam digunakan vertikultur dengan pipa paralon. Sedangkan bibit tauge ditumbuhkan dengan menggunakan container dan kassa basah. Setelah memiliki bibit yang baik, peserta diminta untuk menyiapkan media tanam. Media tanam yang baik terdiri atas 30\% pupuk dan 70\% tanah (Mulasari, 2019). $100 \%$ Peserta terlibat aktif dalam kegiatan dan mendemostrasikan pembuatan vertikultur serta penanaman benih sesuai demostrasi yang diberikan seperti ditunjukkan pada Gambar 5.

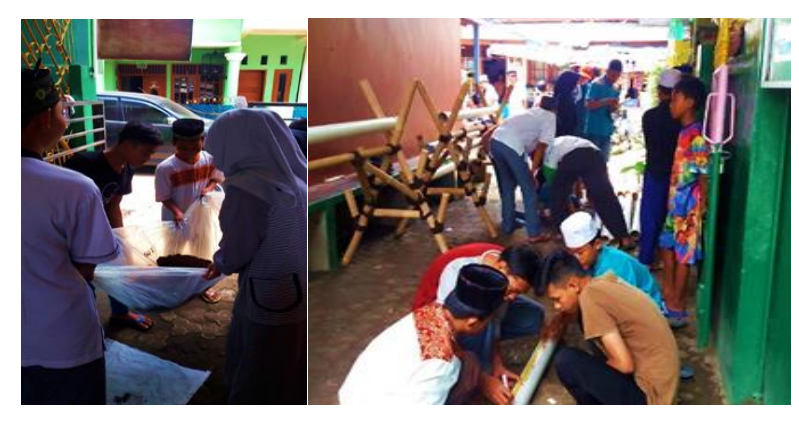

Gambar 5. Partisipasi aktif peserta dalam PKM

Setelah persiapan media tanam kemudian dibuat vertikultur dengan memanfaatkan pipa paralon yang dilubangi di satu sisi dengan menggunakan bor pembolong. Setiap lubang didesain dengan ukuran yang tidak terlalu besar. Selain persiapan pipa vertikultur yang diikat dengan sabut. Tahapan selajutnya adalah penanaman bibit ke media vertikultur. Tahapan selajutnya adalah penanaman bibit tauge dengan menggunakan container dan kassa basah. Bibit tauge dari kacang hijau direndam dengan air hangat selama 10-15 menit kemudian di tebar di kassa yang sudah dibasahi dan ditutup dengan kain strimin. Diulang dengan lapisan lebih dari 2-3 lapisan dan ditutup rapat serta diletakkan di bagian yang gelap. Container didiamkan dan disiram secara rutin setiap hari.

Berdasarkan hasil kegiatan yang diperoleh seluruh peserta terlibat aktif dalam kegiatan serta mampu mendemonstrasikan kembali cara- cara bertanam 
vertikultur dengan menamfaatkan pipa paralon yang dibuat. Pengelola panti asuhan uga berharap kegiatan ini dapat berkesinambungan dilakukan di panti asuhan untuk meningkatkan pengetahuan santri dan juga meningkatkan konsumsi santri akan sayuran yang selama ini sangat terbatas dikarenakan keterbatasan dana bantuan. Pengelola panti asuhan berharap kelak vertikultur dengan menggunakan pipa paralon ini dapat dijadikans alah satu sumber pendapatan panti asuhan.

Media vertikultur yang telah dibuat oleh peserta selanjutnya diletakkan di dua tempat di panti asuhan al hidayah serta panti asuhan roisul falah. Setiap peserta bertanggung jawab untuk merawat tanaman yang mereka buat. Bibit-bibit yang dipilih memiliki masa panen rata- rata 3 bulan. Setelah 3 bulan kegiatan akan dilakukan evaluasi pencapaian di kedua kelompok. Evaluasi dilakukan untuk menilai keberhasilan pembibitan yang telah dibuat.

Hasil akhir kegiatan ini adalah tersedianya vertikultur dengan menggunakan pipa paralon yang dapat menghasilkan sayuran yang bermanfaat bagi santri di panti asuhan. Setelah kegiatan ini diharapkan santri memiliki kemandirian dalam memproduksi sayuran bagi kepentingan panti asuhan dan dalam jangka lama akan mampu memproduksi sayuran dengan nilai ekonomis yang dapat digunakan untuk sumber masukan panti asuhan.

\section{KESIMPULAN}

Dapat disimpulkan bahwa terdapat peningkatan pengetahuan mengenai vertikultur dan ketrampilan dalam membuat vertikultur tanaman sayur seperti yang di demosntrasikan. Kegiatan ini menghasilkan vertikultur di panti asuhan al hidayah yang dapat dimanfaatkan santri di panti asuhan untuk memenuhi kebutuhan akan sayuran.

\section{UCAPAN TERIMA KASIH}

Ucapan terima kasih kepada pengurus panti asuhan al hidayah dan roisul falah Jati Bening. Terima kasih juga ditujukan pada FMIPA UNJ atas bantuan kegiatan dalam skema pengabdian BLU UNJ.

\section{REFERENSI}

Abubakar, R., Alhanannasir, A., Afriatna, S., Kurniawan, R., Apriatni, N. 2019. Pemanfaatan Pekarangan Rumah Dengan Menanam Secara Hidroponik Di Kelurahan 2 Ulu Kecamatan Seberang Ulu 1 Kota Palembang. Suluh Abdi : Jurnal Ilmiah Pengabdian Kepada Masyarakat. 1(1):51-56.

Amilia, E., Joy, B., Sunardi, S. 2016. Residu Pestisida pada Tanaman Hortikultura (Studi Kasus di Desa Cihanjuang Rahayu Kecamatan Parongpong Kabupaten Bandung Barat). Jurnal Agrikultura. 27(1):23-29. https://doi.org/10.24198/agrikultura.v27i1.8 473

Ashari, Saptana, Purwantini, T.B. 2012. Potensi Dan Prospek Pemanfaatan Lahan Pekarangan Untuk Mendukung Ketahanan Pangan. Forum Penelitian Agro Ekonomi. 30(1):13-30. http://dx.doi.org/10.21082/fae.v30n1.2012.1 3-30

Dhunita, W.M.P. 2015. Clustering Menggunakan Metode K-Means Untuk Menentukan Status Gizi Balita. Jurnal Informatika. 15(2):160-174.

Fuaida, L.D. 2012. Kualitas Pengasuhan Anak dan Celah Kekerasan di Panti Sosial Asuhan Anak: Studi Kasus di PSAA Darul Aitam Nahdlatul Wathan, Kabupaten Lombok Timur Provinsi Nusa Tenggara Barat. Empati : Jurnal Ilmu Kesejahteraan Sosial. 1(1):45-58. https://doi.org/10.15408/empati.v1i1.9661

Mulasari, S.A. 2018. Penerapan Teknologi Tepat Guna (Penanam Hidroponik Menggunakan Media Tanam) Bagi Masyarakat Sosrowijayan Yogyakarta. Jurnal Pemberdayaan: Publikasi Hasil Pengabdian Kepada Masyarakat. 2(3):425430. https://doi.org/10.12928/jp.v2i3.418

Prihmantoro, H. 2006. Memupuk Tanaman Sayur. Jakarta: Penebar Swadaya. 
Rachman, H.P.S., Ariani, M. 2008. Penganekaragaman Konsumsi Pangan Di Indonesia: Permasalahan Dan Implikasi Untuk Kebijakan Dan Program. Analisis Kebijakan Pertanian. 6(2):140-154.

http://dx.doi.org/10.21082/akp.v6n2.2008.14 $0-154$

Raharto, A., Noveria, M., Fitranita. 2008. Konsumsi Sayur Dan Buah Di Masyarakat Dalam Konteks Pemenuhan Gizi Seimbang. Jurnal Kependudukan Indonesia. 3(2):97-119. https://doi.org/10.14203/jki.v3i2.171

Rinawati, D., Sofiatun, S. 2019. Kandungan Logam Berat dan Pestisida pada Sayuran Segar di Kota Tangerang. Higiene : Jurnal Kesehatan Lingkungan. 4(3):169-176.

Sarno, S. 2019. Pemberdayaan Karang Taruna Desa Rakit Melalui Kegiatan Budidaya Dan Pengolahan Sayuran Organik. Masyarakat Madani: Jurnal Kajian Islam dan Pengembangan Masyarakat. 4(2):33-43.

http://dx.doi.org/10.24014/jmm.v4i2.7898

Syachruddin, A.R., Karnan, K., Japa, L., Merta, I.W., Mertha, I.G. 2019. Meningkatkan Kualitas Produksi Rumput Laut Melalui Pelatihan tentang Sistem Pengelolaan Budidaya Secara Terpadu di Gili Gede Lombok Barat NTB. Jurnal Pengabdian Magister Pendidikan IPA. 2(1):66-70.

https://doi.org/10.29303/jpmpi.v2i1.356

Wachdijono, W., Wahyuni, S., Trisnaningsih, U. 2019. Sosialisasi Urban Farming Melalui Budidaya Tanaman Sayuran Secara Vertikultur Dan Hidroponik Di Kelurahan Kalijaga, Kecamatan Harjamukti, Kota Cirebon. Qardhul Hasan: Media Pengabdian kepada Masyarakat. $\quad$ 5(2):90-94. http://dx.doi.org/10.30997/qh.v5i2.1928

Yasin, S.M., Kasim, N.N. 2018. Pemanfaatan Pekarangan Menjadi Kebun Sayur Produktif Di Daerah Pesisir Di Kecamatan Wara Timur. To Maega : Jurnal Pengabdian Masyarakat. 1(1):1-7. http://dx.doi.org/10.35914/tomaega.v1i1.67

Zubaidah, S., Sustiyah, S., Asie, K.V. 2020. Pengembangan Tanaman Sayuran Organik di Pondok Pesantren Darul Amin Kota Palangka Raya. Pengabdian Kampus : Jurnal Informasi Kegiatan Pengabdian Pada Masyarakat. 7(1):5-13. 